\title{
HEURISTIC REASONING AND THE APPLICATION OF THE CONCEPT OF FUZZY DECISION VARIABLES IN THE QUANTITATIVE RISK ANALYSIS OF CONSTRUCTION ProjeCtS IN Nigeria
}

\author{
Ibrahim Yakubu \\ Department of Quantity Surveying, Faculty of Environmental Technology, \\ Abubakar Tafawa Balewa University, P.M.B. 0248, Bauchi, \\ Bauchi State, Nigeria
}

\begin{abstract}
The study has utilized heuristic reasoning and the concept of Fuzzy Decision Variables in order to undertake the risk analysis of a proposed construction project in a selected domain The objectives included determining the sources of risks, obtaining the Fuzzy Decision Variables by deductive reasoning, identifying the types of risks prevailing in the project and the utilization of fuzzy set analysis in order to estimate the possible magnitudes of the risks. Five completed projects were analysed. For each project, a breakdown of the final contract sum into variations, remeasurement of provisional quantities, nominated subcontractors' accounts, nominated suppliers' accounts, loss and expense caused by disturbances of regular progress of the works, fluctuation in rates of labour and prices of materials was undertaken in order to derive the sources of risks, the Fuzzy Decision Variables and the subsequent risks. Fuzzy set analysis was used to calculate the possible magnitudes of the risks. Heuristic reasoning and fuzzy set analysis could be used in a composite framework to undertake the risk analysis of a proposed project in a selected domain.
\end{abstract}

\section{KEYWORDS}

Heuristic reasoning, Fuzzy Decision Variables, risk and fuzzy set analysis

\section{INTRODUCTION}

Every client executing construction projects should be capable of managing risks that could occur in his projects. Risk management involves the identification and quantification of risks so that appropriate plans could be erected for the purpose of mitigating such risks.

The aim of the study is to utilize heuristic reasoning and fuzzy set analysis for the purpose of identifying risks and assessing the monetary magnitudes of risks that could occur in a proposed construction project in a selected domain.

The objectives of the study are as follows:

1) To identify the sources of risks that cause financial impacts on construction projects

2) To identify the Fuzzy Decision Variables that give rise to these risks at the initial stages of design

Natarajan Meghanathan et al. (Eds) : ICCSEA, WiMoA, SCAI, SPPR, InWeS, NECO - 2019 
3) To identify the types of risks prevailing in the project

4) To assess the likely magnitudes of the Fuzzy Decision Variables

The study would recommend a framework that would provide a means of identifying risks and estimating the financial impact of risk-associated consequences for proposed construction projects to be executed by the selected client.

\section{Literature REVIEW}

Risk has been defined as "an uncertain event or condition that, if it occurs will have either a positive or negative effect on one or more project objectives" (Project Management Institute, 2008). Odeyinka (2003) have indicated how the construction industry is being faced with a variety of situations that involve a lot of unknowns, unexpected and unpredictable factors.

Hwang (2013) has used the Bayesian approach to measure risk. Kahneman et al (1982) have refuted the effectiveness of Bayes' rule and other well-known statistical laws as psychological hypothesis about everyday decision-making. An RICS Research (2012) used the Artificial Neural network Modelling technique to evaluate the impacts on the variability between contract sum and final account. In dealing with risk in tender prices, most contractors apply a series of rules of thumb (Al-Bahar and Crandall, 1990).

\section{Methodology}

Ibrahim (2008) has described an approach that could be utilized in predicting risks in a particular construction project by perusing project data such as drawings, bills of quantities and specifications and estimating the prevalence of Fuzzy Decision Variables (FDVs).

A Fuzzy Decision Variable (FDV) for a particular risk event denotes a condition in a risk environment, which predisposes the occurrence of that risk in the environment (Bala and Yakubu, 2008). The concept of FDVs has been proposed as a tool for the risk analysis of construction projects in selected domains (Ibrahim 2007 and Ibrahim 2008). FDVs are used as variables for assessing monetary consequences of risks.

To perceive the role of FDVs in the occurrence of risks in construction projects, it is worthwhile to review the Reason's model of organizational accidents:

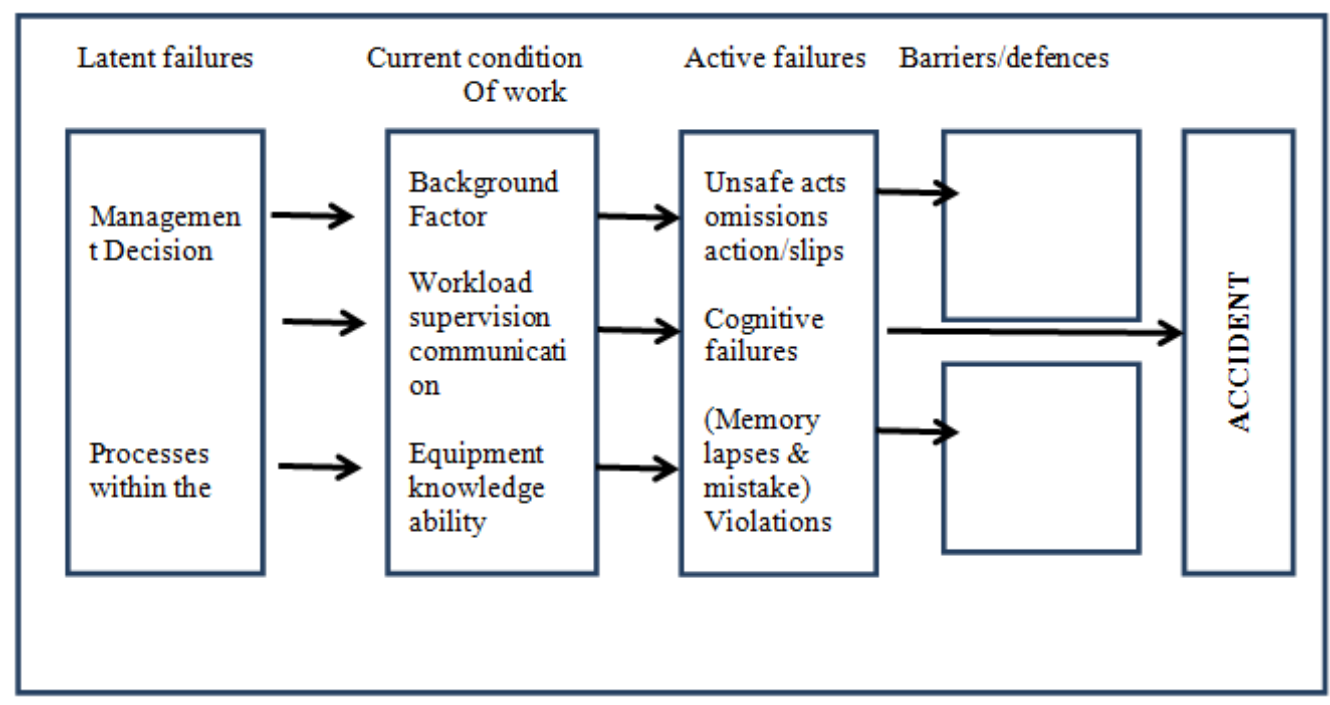

Figure 1 Reason's model of organisational accidents Source: Reason (1995) 
The Reason's model of investigating accidents (Reason, 1995) was initially developed following large-scale accidents, such as the Piper Alpha offshore oil drilling platform disaster and the King's Cross fire of London (Thompson and Pretlove, 2002). The aim of the model is to examine the conditions that are present when an accident happens, including restraints that might have placed by management. These latent factors establish the environment within which the active failure could have occurred.

In transposing this organizational model into a construction project system, it is easy to identify latent failures as potential sources of risk inherent in a project structure; current conditions of work as the prevailing conditions of the project environment; and active failures as deliberate risk factors occurring in the risk environment. The barriers/defences could be construed as plans or measures erected in the project structure for the purpose of mitigating or preventing the occurrence of the risk. Finally, accidents could be replaced by cost, schedule or quality failures developing as a result of the occurrence of risk events.

\subsection{Identification of Risks}

Dewhurst and Gwinnet (1992) have indicated that logical deduction is one of the skills used by human beings in the process of decision-making. Production rules are formalism for the human thought processes (Siler, 2000). The models of plausible reasoning (Polya, 1969) are based on the rule: IF A THEN B

These models define patterns, which can be used sensibly in argument. In practice, there is usually more than one symptom, or evidence, i.e. the rule is usually:

$\mathrm{A}=>\mathrm{B}_{1}, \mathrm{~B}_{2}, \mathrm{~B}_{\mathrm{n}}$

Evidence of a single symptom Bi tells little about A. however, a plausible line of reasoning is (Hart, 1986):

" $\mathrm{B}_{3}$ is true. $\mathrm{I}$ also know that $\mathrm{B} 1$ and $\mathrm{B} 2$ are true, and that $\mathrm{B} 3$ is different from them so this makes A more credible"

A heuristic is a bit of anecdotal information acquired by experience which can be applied to decisions in future situations which are similar, but not quite the same. In the real world, nearly every human expert makes decisions based on data which are to some extent incomplete, unreliable, ambiguous and dynamic (Keller, 1987). In making quantitative estimates about uncertain events, experts and laymen tend to rely on heuristic strategies rather than computationally demanding statistical rules (Slatter, 1987).

In order to identify the risks that could cause differences between initial contract sums and final contract sums, the factors that cause differences between initial contract sums and final contract sums must be analysed. This would reveal the FDVs that cause the emergence of these factors.

Goble (1981) has described structured system analysis methodology as "taking the problem area in the most general form and then refining it in a structured and systematic manner until the finest levels of details are obtained.

The adjustment of the contract sum in the final account falls under the following headings:

i. Variations

ii. Remeasurement of provisional quantities

iii. Nominated subcontractors' accounts

iv. Nominated suppliers' accounts 
v. Loss and expense caused by disturbances of regular progress of the works

vi. Fluctuation in rates of labour and prices of materials

The design briefing for a new building or the replacing of an existing building may be organised in the following steps (Worthington (1994):

- Strategic brief

- Concept brief

- Detailed brief

- Facilities management brief

Ibrahim (2010) has described how the issue of variation arises due to the following FDVs:

i. Inadequate strategic briefing-indicated by inadequacy of size, shapeliness of building and ability to meet growth and change

ii. Inadequate concept briefing-indicated by unserviceability of building

iii. Inadequate detailed briefing-indicated by poor specification of fine details

iv. Inadequate facilities management briefing-indicated by poor planning of total life-cycle of a building

The Aqua Group (1990) has stressed the importance of having the following drawings prepared before tender stage is reached:

- Specialist Consultants designs

- Architect's Services designs

- Building designs

- Construction designs

- Finishes and materials specifications

According to Ibrahim (2010), any inadequacy or non-availability of the above drawings could likely result into an ill-defined scope. Hence inadequacy of Consultants' designs is an FDV and it is indicated by deficiencies of the above-listed drawings.

The risk of unknown unknown (Smith, 1999) is indicated by the FDV of unknown unknown which is an unknown latent condition that cannot be defined, nor identified and is not estimable in terms of effect; yet it could precipitate concrete adjustment in the initial contract sum. Since a provisional sum is a sum provided for a cost which cannot be entirely foreseen, defined or detailed at the time of tendering, it is appropriate to denote such FDV that could cause the adjustment of provisional sums as an unknown unknown.

The FDV of long contract period predicts the likelihood of occurrence of the risk of inflation.

The FDVs are derived by perusing through project data and noting the specific events that highlighted these variables. Consequently, from theses risk events, likely indicators for the FDVs could be built-up. The purpose of deriving these indicators is to construct a repository of signals within which a search for the project characteristics for a proposed project could be executed. When the analysis of a new project is contemplated, the project characteristics would be examined and an attempt would be made to match these project characteristics with the indicators of the FDVs in the repository. Once a match is confirmed, the prevalence of the FDV could be announced. The underlying precept for this approach is that the presence of at least one indicator is a sufficient indicator for the likely occurrence of the FDV. 


\subsection{Evaluation of Risk Magnitudes}

The strength or density of an FDV indicates the likelihood by which that FDV could cause the occurrence of that risk. Human expertise is heavily based on having large compilations of heuristics combined with some skill in knowing when and how to apply them (Keller, 1987).

Therefore, the occurrence of a risk is precipitated if its FDVs are significant in concentration. The theory of fuzzy mathematics is utilized in the evaluation of magnitudes of risk-associated consequences of the risks precipitated by FDVs; hence the appellation 'Fuzzy Decision Variables'.

The fuzzy set approach is useful for uncertainty analysis where a probabilistic data base is not available (Bogardi and Bardossy, 1983). The main advantage of fuzzy set analysis is that it is an estimating technique that is based on human judgment, where data on recently executed projects is limited (Paek et al, 1993). In the real world, nearly every human expert makes decision based on data which are to some extent incomplete, unreliable, ambiguous and dynamic (Keller, 1987).

Zadeh (1965) introduced the notion of fuzzy sets. Fuzziness represents situations where membership of sets cannot be defined on a yes or no basis because the boundaries of the set are vague. If an element is a member of a fuzzy set to some degree, the value of its membership function is a generalization of this concept to represent partial belonging, partial truth, and partial compatibility (Amey, 1979). The notion central to fuzzy systems is that truth values (in fuzzy logic) or membership values (in fuzzy sets) are indicated by a value on the range [0.0, 1.0], with 0.0 representing absolute Falseness and 1.0 representing absolute Truth.

Paek et al (1993) has indicated how five samples of a variable could suffice in the fuzzy analysis of a variable.

The total net loss, $\mathrm{T}_{\mathrm{h}}$, varies with the membership degree $\mathrm{h}$. with the help of two values, $\mathrm{Th}=0$ and $\mathrm{Th}=1$, the total net loss, $\mathrm{T}$, can be estimated as a fuzzy number with the following membership functions (Lee et al, 1991):

$\mu(\mathrm{T})=1, \quad \alpha<\mathrm{T}<\beta$.

$\mu(\mathrm{T})=(\mathrm{T}-\mathrm{A}) /(\alpha-\mathrm{A}), \mathrm{A}<=\mathrm{T}<\beta$

$\mu(\mathrm{T})=(\mathrm{T}-\mathrm{B}) /(\beta-\mathrm{B}), \beta<=\mathrm{T}<=\mathrm{B}$
$\mu(\mathrm{T})=0, \ldots$

where $\mathrm{A}$ and $\mathrm{B}=$ the lower and upper-bound values, respectively, of the $\mathrm{Th}=0$; and $\alpha$ and $\beta$; the lower-bound and upper-bound values, respectively, of $\mathrm{Th}=1$.

To transform the fuzzy number $\mathrm{T}$ into a crisp value that represents the fuzzy number $\mathrm{T}$, a ranking method developed by Chen (1985) is used. In this method, the crisp value RC can be expressed as:

$\mathrm{RC}=(\mathrm{V} 1+\mathrm{V} 2) / 2(\mathrm{~W} 1+\mathrm{W} 2)$

Where V1, V2, W1 and W2 are subjects of the formulae defined as follows (Chen 1985):

$\mathrm{V} 1=\mathrm{B} 3(\mathrm{~B}+3 \alpha-3 \mathrm{~A})-\mathrm{B} 2(4 \alpha \mathrm{A}+\beta \mathrm{A}+\alpha \beta)$

$\mathrm{V} 2=\mathrm{A} 3(3 \mathrm{~B}-3 \beta-\mathrm{A})+\mathrm{A} 2(4 \beta \mathrm{B}+\alpha \mathrm{B}+\alpha \beta)$

(7)

$\mathrm{W} 1=\mathrm{B} 2(2 \mathrm{~B}-7 \mathrm{~A}+\beta+2 \alpha) 3(\mathrm{AB})(\beta-\alpha)$

$\mathrm{W} 2=\mathrm{A} 2(7 \mathrm{~B}-2 \mathrm{~A}-2 \beta+\alpha)-(\alpha \beta)(\mathrm{B}-\mathrm{A})$ 
If the value $\mathrm{RC}$ has a negative sign, (i.e., $\mathrm{RC}<0$ ), it means that the sum of gains is greater than the losses. Otherwise; the sum of the losses is greater than the sum of the gains.

For the purpose of estimating risk-associated consequences, it would be expedient to construct membership functions in accordance to with equations (1) - (4) for each FDV identified in the particular domain of projects. This would necessitate determining the lower and upper bound values of the most likely interval and the lower and upper bound values of the largest likely interval for each FDV.

The largest likely interval is the range between the minimum and the maximum values among the five values of the range of the variable. The most likely interval would then be the range between the two values around the average of the five values.

The strategy to be adopted in this study is to obtain the values of the consequences of the FDV wherever it had occurred in all the five projects and subsequently derive the lower and upper bound values of the most likely interval and the lower and upper bound values of the largest likely interval. These two intervals would then be utilized in calculating the crisp value for each FDV in accordance with equations (5) - (9).

\subsection{Case Study}

A major objective of the study was to derive the Fuzzy Decision Variables (FDVs) of an executed construction project in a selected domain. A Case Study of a project was undertaken in order to articulate the methodology for the derivation of the FDVs. The salient features of the project are as follows:

Project: Students' hostel

Type of costruction: Reinforced concrete frame with blockwork cladding

Initial conract sum: $\mathrm{N} 31,159,672.50$

Final contract sum: N37, 095,629.51

Contract period: 58 weeks

Completion period: 121 weeks

Analysis of final contract sum

The final contract sum increased over the initial contract sum by $19.05 \%$. table 1 gives the breakdown of the final contract sum for the project.

Table1. Breakdown of final contract sum

\begin{tabular}{|l|l|l|}
\hline S/no. & Description & $\begin{array}{l}\text { Percentage difference in contract sum caused by } \\
\text { item } \\
\mathbf{( \% )}\end{array}$ \\
\hline 1. & Adjustment of PC sum & +3.46 \\
\hline 2. & Adjustment of provisional sums & -5.49 \\
\hline 3. & Variations & +3.41 \\
\hline 4. & Remeasurement & -2.70 \\
\hline 5. & Fluctuations & +20.37 \\
\hline & $\begin{array}{l}\text { Total percentage difference in contract } \\
\text { sums }\end{array}$ & +19.05 \\
\hline
\end{tabular}

Fluctuations in both materials and labour costs contributed towards the total fluctuation. Table 2 shows that labour fluctuation had increased the initial contract sum by $4.52 \%$. 
Table2. Breakdown of total fluctuation affecting the project

\begin{tabular}{|l|l|l|}
\hline S/no. & Description & $\begin{array}{l}\text { Percentage difference in contract sum } \\
\text { caused by item } \\
(\mathbf{\%})\end{array}$ \\
\hline 1. & Labour fluctuation & +4.52 \\
\hline 2. & Material fluctuation & +15.85 \\
\hline & $\begin{array}{l}\text { Net difference to the initial contract sum caused } \\
\text { by total fluctuation }\end{array}$ & +20.37 \\
\hline
\end{tabular}

The contractor had increased labour rates twice during the execution of the project as aresult of new economic policies introduced by the Federal Government. Material fluctuation caused an increase of $15.85 \%$.The initial contract period was 58 weeks. This was more than a year. The project was susceptible to fluctuation on account of its initial contract period being more than a year. Therefore the FDV in this situation is inflation.

Adjustment of provisional sums decreased the initial contract sum by $-5.49 \%$.

Table 3 lists the items of work covered by provisional sums and the effects of their adjustments in the initial contract sum.

Table3. Items of work covered by provisional sums and the effects of their adjustment on the initial contract sum

\begin{tabular}{|l|l|l|l|}
\hline S/no & Description & $\begin{array}{l}\text { Percentage contribution of } \\
\text { item to total provisional } \\
\text { sum }(\%)\end{array}$ & $\begin{array}{l}\text { Percentage difference in } \\
\text { contract sum caused by item } \\
(\%)\end{array}$ \\
\hline 1. & Additional foundations & $13.08 \%$ & $-0.80 \%$ \\
\hline 2. & Burglar-proofing & $2.17 \%$ & $+0.12 \%$ \\
\hline 3. & Contingencies & $83.85 \%$ & $-4.81 \%$ \\
\hline & & $\begin{array}{l}\text { Net difference to the initial } \\
\text { contract sum caused by total } \\
\text { fluctuation }\end{array}$ & -5.49 \\
\hline
\end{tabular}

Consequently, the FDV for this sector of costs with uncertainty is that of unknown unknown, and it had precipitated a decrease of $5.49 \%$ to the initial contract sum.

The adjustment of prime cost sums caused an increase of $+3.46 \%$ to the initial contract sum. Assuming that the consultants had verified and confirmed their designs before contract award, there ought not be any adjustment of the prime cost sums at the post contract stage. To understand this notion further, it would be appropriate to recall what transpired during a site meeting; when the electrical subcontractor had complained that the quantities in the bills of quantities were actually less than what was actually required in the works. The adjustment of prime cost sums had led to a $60 \%$ increase over the initial prime cost sum provided in the bills of quantities. This kind of development typically illustrates the effect of inadequate design. Therefore, an FDV of inadequate consultants' designs is indicated in this respect and it had precipitated a $3.46 \%$ increase over the initial contract sum.

Variations resulted into an overall increase of $3.41 \%$ over the initial contract sum. Table 4 shows the percentage differences to initial contract sum caused by the various types of variations that had occurred in the project. 
Table 4. Percentage difference in the initial contract sum caused by the various types of variations

\begin{tabular}{|l|l|l|l|}
\hline S/no & Type of variation & $\begin{array}{l}\text { Percentage contribution of } \\
\text { type of variation to total } \\
\text { variation (\%) }\end{array}$ & $\begin{array}{l}\text { Percentage increase over the } \\
\text { initial contract sum caused by } \\
\text { type of variation (\%) }\end{array}$ \\
\hline 1. & $\begin{array}{l}\text { Variation caused by } \\
\text { consultants }\end{array}$ & $29.20 \%$ & $+1.00 \%$ \\
\hline 2. & $\begin{array}{l}\text { Variation caused by } \\
\text { client }\end{array}$ & $70.80 \%$ & $+2.41 \%$ \\
\hline 3. & Total variations & $100.00 \%$ & $+3.41 \%$ \\
\hline
\end{tabular}

Table 4 shows that variations requested by the client had the highest effect on the initial contract sum $(2.41 \%)$ and these variations had constituted the highest percentage $(70.80 \%)$ of the total variations.

The only variations requested by the client were in regard to the construction of roads and parking areas of the new hostel. These were works that should have been catered for at the strategic briefing stage; and therefore, the FDV responsible for the occurrence of these works was inadequate strategic briefing (with an increase of $+2.41 \%$ ).

Table 5 lists the main cost-significant items of work requested by the consultants. They included additional gate, reinforced concrete counter, cat ladder, manhole cover and culvert. These items of work are caused mainly by inadequate architectural services design and the FDV had increased the initial contract sum by $0.73 \%$.

Table 5. Breakdown of variations requested by the consultants in the project

\begin{tabular}{|c|c|c|c|}
\hline S/no & Description & $\begin{array}{c}\text { Percentage contribution of } \\
\text { item to sum of variations } \\
\text { requested by consultants } \\
(\%)\end{array}$ & $\begin{array}{c}\text { Percentage difference over } \\
\text { the initial contract sum } \\
\text { caused by item }(\%)\end{array}$ \\
\hline 1. & $\begin{array}{c}\text { Gate, door, reinforced } \\
\text { concrete counter, cat } \\
\text { ladder, manhole cover } \\
\text { and culvert }\end{array}$ & 73.66 & $+0.73 \%$ \\
\hline 2. & Repair of project vehicle & $26.34 \%$ & $+0.26 \%$ \\
\hline 3. & $\begin{array}{c}\text { Total percentage } \\
\text { difference to the initial } \\
\text { contract sum arising } \\
\text { from variations due to } \\
\text { the consultants }\end{array}$ & $100.00 \%$ & $+0.99 \%$ \\
\hline
\end{tabular}

The final account represents quantities of work that had been initially measured in the bills of quantities; and had been found to have varied after remeasurement upon execution. Thus remeasurement could possibly have arisen as a result of inaccurate measurement at the bills of quantities stage and thus could be attributed to the FDV of inadequate consultants' designs and it has caused a decrease of $2.70 \%$ over the initial contract sum.

Table 6 lists all the FDV's encountered in the project; together with their percentage effects on the initial contract sum. 
Table6. Fuzzy decision variables and their percentage effects on the initial contract sum

\begin{tabular}{|l|l|l|}
\hline S/no & Fuzzy decision variable & $\begin{array}{l}\text { Percentage difference to the initial contract } \\
\text { sum caused by the fuzzy decision variable } \\
(\boldsymbol{\%})\end{array}$ \\
\hline 1. & Inflation & $+15.85 \%$ \\
\hline 2. & Unknown unknown & $-5.49 \%$ \\
\hline 3. & Inadequate consultants' design & $+3.46-2.70=+0.76$ \\
\hline 4. & Inadequate strategic brief & $+2.41^{\prime \prime}$ \\
\hline 5. & $\begin{array}{l}\text { Inadequate architectural services' } \\
\text { designs }\end{array}$ & +0.73 \\
\hline
\end{tabular}

The FDV's are derived by perusing through project files and noting the specific events that highlighted these variables. Subsequently, from these risk events likely indicators for the FDV's could be built-up. The purpose of driving these indicators is to construct a repository of signals within which a search for the project characteristic for a proposed project could be executed. When the analysis of a new project is contemplated, the project characteristics would be presented and an attempt would be made to match these project characteristics with indicators of the FDV's in the repository. Once a match is confirmed, the prevalence of the particular FDV could be announced. The underlying precept for this approach is that the presence of at least one indicator is a sufficient indicator for the likely occurrence of an FDV.

Table 7 shows all fuzzy decision variables that have been encountered in the five projects; together with the percentage differences to the initial contract caused by each fuzzy decision variable in each project. 
Table7. Fuzzy decision variables and their percentage differences in the initial contract sums of the five project

\begin{tabular}{|c|c|c|c|c|c|c|c|}
\hline $\begin{array}{l}\mathbf{S} / \\
\mathbf{N} \\
\text { o. }\end{array}$ & $\begin{array}{l}\text { Fuzzy } \\
\text { Decision } \\
\text { Variable }\end{array}$ & $\begin{array}{l}\text { Percentage } \\
\text { difference } \\
\text { to the } \\
\text { initial } \\
\text { contract } \\
\text { sum in } \\
\text { Project I } \\
(\%)\end{array}$ & $\begin{array}{l}\text { Percentage } \\
\text { difference } \\
\text { to the initial } \\
\text { contract } \\
\text { sum in } \\
\text { Project II } \\
\text { (\%) }\end{array}$ & $\begin{array}{l}\text { Percentage } \\
\text { difference } \\
\text { to the } \\
\text { initial } \\
\text { contract } \\
\text { sum in } \\
\text { Project III } \\
\text { (\%) }\end{array}$ & $\begin{array}{l}\text { Percentage } \\
\text { difference to } \\
\text { the initial } \\
\text { contract sum } \\
\text { in Project IV } \\
(\%)\end{array}$ & $\begin{array}{l}\text { Percentage } \\
\text { difference } \\
\text { to the } \\
\text { initial } \\
\text { contract } \\
\text { sum in } \\
\text { Project } \\
\text { V(\%) }\end{array}$ & $\begin{array}{l}\text { Average } \\
\text { absolute } \\
\text { value of } \\
\text { percentage } \\
\text { difference } \\
\text { to the } \\
\text { initial } \\
\text { contract } \\
\text { sum in all } \\
\text { projects } \\
(\%)\end{array}$ \\
\hline 1 & $\begin{array}{l}\text { Inadequate } \\
\text { engineering } \\
\text { consultant } \\
\text { design }\end{array}$ & +43.40 & +3.36 & +6.61 & +3.39 & +0.76 & 11.50 \\
\hline 2 & $\begin{array}{l}\text { Inadequate } \\
\text { architectural } \\
\text { building } \\
\text { design }\end{array}$ & +1.87 & +1.51 & +0.53 & 0.00 & 0.00 & 0.78 \\
\hline 3 & $\begin{array}{l}\text { Inadequate } \\
\text { architectural } \\
\text { services } \\
\text { design }\end{array}$ & +1.61 & +0.61 & 0.00 & _0.97 & +0.73 & 0.78 \\
\hline 4 & $\begin{array}{l}\text { Inadequate } \\
\text { strategic } \\
\text { briefing }\end{array}$ & +1.46 & +4.63 & +1.12 & +0.13 & +2.41 & 1.95 \\
\hline 5 & $\begin{array}{l}\text { Inadequate } \\
\text { concept } \\
\text { briefing }\end{array}$ & +11.04 & +6.52 & 0.00 & +1.46 & 0.00 & 3.80 \\
\hline 6 & $\begin{array}{l}\text { Inadequate } \\
\text { detailed } \\
\text { briefing }\end{array}$ & +5.51 & 0.00 & 0.00 & 0.00 & 0.00 & 1.10 \\
\hline 7 & $\begin{array}{l}\text { Long } \\
\text { contract } \\
\text { period }\end{array}$ & +7.58 & +18.61 & +31.12 & +5.59 & +15.85 & 15.75 \\
\hline 8 & $\begin{array}{l}\text { Unknown } \\
\text { unkown }\end{array}$ & -5.00 & +1.48 & 0.00 & _5.39 & 5.49 & 3.47 \\
\hline
\end{tabular}

After obtaining all values for the fuzzy decision variables from the five projects, the next procedure would be to determine the largest and the most likely interval for the fuzzy decision variables. In constructing the membership function of a fuzzy variable, the largest likely interval is the range between the minimum and the maximum values among the five values of range of the variable. The most likely interval would then be the ranges between the two values around the average of the five values.

Table 8 shows the largest likely interval and the most likely interval for all the fuzzy decision variables encountered in the five projects. 
Table8. Largest likely intervals and most likely intervals for fuzzy decision variables

\begin{tabular}{|l|l|c|c|c|c|}
\hline S/No & \multirow{2}{*}{ Fuzzy Decision Variable } & \multicolumn{2}{|c|}{ Largest Likely Interval } & \multicolumn{2}{c|}{ Most Likely Interval } \\
\cline { 3 - 5 } & & $\mathrm{A}$ & $\mathrm{B}$ & $\mathrm{A}$ & $\beta$ \\
\hline 1 & $\begin{array}{l}\text { Inadequate engineering } \\
\text { consultant design }\end{array}$ & 0.76 & 43.40 & 6.61 & 43.40 \\
\hline 2 & $\begin{array}{l}\text { Inadequate architectural } \\
\text { building design }\end{array}$ & 0.00 & 1.87 & 0.53 & 1.87 \\
\hline 3 & $\begin{array}{l}\text { Inadequate architectural } \\
\text { services design }\end{array}$ & 0.00 & 1.61 & 0.73 & 0.97 \\
\hline 4 & Inadequate strategic briefing & 0.13 & 4.63 & 1.46 & 2.41 \\
\hline 5 & Inadequate concept briefing & 0.00 & 11.04 & 1.46 & 6.52 \\
\hline 6 & Inadequate detailed briefing & 0.00 & 5.51 & 0.00 & 5.51 \\
\hline 7 & Long contract period & 5.59 & 31.12 & 7.58 & 15.85 \\
\hline 8 & Unknown unkown & 0.00 & 5.49 & 0.00 & $\ldots 5.00$ \\
\hline
\end{tabular}

Table 9 shows the crisp values of the possible magnitudes of the FDVs. Hence the likely cost effects of prevailing risks could estimated by finding the arithmetical sum of the cost effects of all FDVs identified in project proposed to be executed in the domain contemplated.

Table9. Crisp values for the fuzzy decision variables

\begin{tabular}{|c|c|c|c|c|c|c|c|c|}
\hline $\begin{array}{l}\text { S/ } \\
\text { No }\end{array}$ & $\begin{array}{l}\text { Fuzzy } \\
\text { Decision } \\
\text { VariableFDV }\end{array}$ & V1 & $\mathrm{V2}$ & W1 & W2 & $\mathrm{V} 1+\mathrm{V} 2$ & $2(W 1+W 2)$ & $\mathbf{R C}$ \\
\hline 1 & $\begin{array}{l}\text { Inadequate } \\
\text { Specialist } \\
\text { consultants }\end{array}$ & $\begin{array}{l}43421 \\
29.00\end{array}$ & -4683.51 & 92986.18 & $\begin{array}{c}- \\
12104.0 \\
0\end{array}$ & $\begin{array}{c}4337445.0 \\
0\end{array}$ & 161764.30 & $\begin{array}{c}26.8 \\
1\end{array}$ \\
\hline 2 & $\begin{array}{l}\text { Inadequate } \\
\text { architectural } \\
\text { building } \\
\text { design }\end{array}$ & 19.16 & 0.00 & 10.25 & -1.85 & 19.16 & 16.76 & 1.14 \\
\hline 3 & $\begin{array}{l}\text { Inadequate } \\
\text { architectural } \\
\text { services design }\end{array}$ & 14.02 & 0.00 & 9.62 & -1.14 & 14.02 & 16.95 & 0.83 \\
\hline 4 & $\begin{array}{l}\text { Inadequate } \\
\text { strategic } \\
\text { briefing }\end{array}$ & 757.14 & 0.91 & 188.22 & -15.85 & 786.23 & 345.74 & 2.19 \\
\hline 5 & $\begin{array}{l}\text { Inadequate } \\
\text { concept } \\
\text { briefing }\end{array}$ & $\begin{array}{c}19688 . \\
52\end{array}$ & 0.00 & 2252.37 & -105.09 & 19588.52 & 4294.56 & 4.56 \\
\hline 6 & $\begin{array}{l}\text { Inadequate } \\
\text { detailed } \\
\text { briefing }\end{array}$ & 921.74 & 0.00 & 167.28 & 0.00 & 921.74 & 334.57 & 2.76 \\
\hline 7 & $\begin{array}{l}\text { Long contract } \\
\text { period }\end{array}$ & $\begin{array}{c}75152 \\
7.90\end{array}$ & $\begin{array}{c}- \\
65752.60\end{array}$ & 17396.78 & 2636.78 & 685775.30 & 40067.12 & $\begin{array}{c}17.1 \\
2\end{array}$ \\
\hline 8 & $\begin{array}{l}\text { Unknown } \\
\text { unk nown }\end{array}$ & 908.43 & 0.00 & 180.24 & 0.00 & 908.43 & 360.48 & 2.52 \\
\hline
\end{tabular}

For example, design risk is precipitated by the following FDVs .Table 10 shows the total crisp value accruing to design risk 


\begin{tabular}{|l|l|l|}
\hline S/No. & Fuzzy Decision VariableFDV & RC \\
\hline 1. & Inadequate Specialist consultants & 26.81 \\
\hline 2. & Inadequate architectural building design & 1.14 \\
\hline 2. & Inadequate architectural services design & 0.83 \\
\hline 3. & Inadequate strategic briefing & 2.19 \\
\hline 4. & Inadequate concept briefing & 4.56 \\
\hline 5. & Inadequate detailed briefing & 2.76 \\
\hline & TOTAL & 38.29 \\
\hline
\end{tabular}

Hence, for a project contemplated by this client, design risk could likely cause a $38 \%$ increase in the initial contract sum. Similarly, the risk of inflation could cause $17 \%$ increase; and the risk of unknown unknown could cause $3 \%$ increase over the initial contract sum

\section{SUGGESTION FOR IMPLEMENTATION}

The fulcrum of knowledge-based system development is to elicit domain-specific information from experts, represent such knowledge using an appropriate representation in a computer program for the purpose of solving human activity problems. The concept of Fuzzy Decision Variables, heuristic reasoning and fuzzy set analysis could be used as a framework to develop a knowledge-based system for the purpose of undertaking risk analysis in a selected domain.

Ibrahim (2019) has developed a knowledge-based system using JAVA programming language and Graphic user interface built on Oracle NetBeans IDE 7.3 Beta.

\section{CONClusion}

For the purpose of undertaking the risk analysis of construction projects in a selected domain, it is possible to derive the Fuzzy Decision Variables that could indicate the potential or hidden risk in the project. The identification of such risks could be done using heuristic reasoning using the presence of the derived Fuzzy Decision Variables as criterion. The possible magnitudes of such risks could then be estimated by utilising fuzzy set analysis.

\section{REFERENCES}

[1] Al-Bahar, J.E. and Crandall, K.C. (1990)," Risk Management Approach for Construction Projects", Journal of Construction Engineering and Management, ASCE, 116 (3), pp. 533-543.

[2] Aqua Group (1990), Tenders and Contracts for Building, BSP.

[3] Bala, K. AND Yakubu, I. (2008), "The Application of Fuzzy Decision Variables for Evaluating Risk Associated Consequences in Construction Projects", Nigerian journal of Construction Technology and Management,Vol.9(1), pp 42-49.

[4] Blok, F.G. (1982), "Contingency, Definition, Clarification and Probability", Proceedings, 7th Intl. Construction Engineering Congress Paper B-3, London, England.

[5] Bogardy, I. and Bardossy, A. (1983), “ Regional Management of an Aquifer for Mining under Fuzzy Environmental Objectives”, Water Resource Research, 19(6), pp $1394-1402$.

[6] Chasey, A.D. and Guo, J, (2000), "Preproject Planning for Microelectronics Facilities", Cost Engineering, 42(3), pp $38-44$.

[7] Chakraborty, U. K. and Dastidar, D.G. (1995), Software and System Development: An Introduction, Wheeler Publishing, New Delhi, India. 
[8] Chen, S.H. (1985)," Ranking Fuzzy Numbers with Maximizing Set and Minimizing Set”, Fuzzy Sets System 17(2), pp $113-129$.

[9] Dewhurst, F. G. and Gwinnet, E. A. (1992)," Artificial intelligence and Decision Analysis", In: Doukidis, G. I. and Paul, R. J. (Eds) (1992), Artificial Intelligence in Operational Research, Basingtoke: Macmillan Press.

[10] Flanagan, R.E. and Norman, G. (1993), Risk Management and Construction, Blackwell Scientific Publications.

[11] Goble, T. (1989), Sructured Systems Analysis through PROLOG, Prentice Hall International Ltd.

[12] Hart, A. (1986), Knowledge Acquisition for Expert Systems, McGraw-Hill Book Company.

[13] Hwang, S. (2013)," Probabilistic Measurement of Risk Associated with Initial Estimates", Proceedings of the 5th International Conference on Construction Engineering and Project, Orange County, California, January 9 - 11, 2013.

[14] Ibrahim, Y. (2007)," The Application of Knowledge Engineering in Risk Management: Heuristicbased Reasoning in the Qualitative Risk Analysis of Proposed Construction Projects", Journal of Construction Management and Engineering, Vol. 1 No.1, pp: 86-97.

[15] Ibrahim, Y. (2008), Modeling the Risk Analysis Process for Construction Projects in Nigeria, Unpublished PhD Thesis, Department of Building, Ahmadu Bello University, Zaria, Nigeria.

[16] Ibrahim, Y. (2019), "Development of Knowledge-based System for undertaking the Risk Analysis of Proposed Building Projects for a Selected Client", Proceedings of the 6th International Conference on Data Mining and Database, Vancouver, Canada from May $25^{\text {th }}$ to May $26^{\text {th }}, 2019$.

[17] Kahneman, A. Slovic, P. and Tversky, A. (1982), Judgment under Uncertainty: Heuristics and Biases, England: Cambridge University Press.

[18] Keller, R. (1987), Expert Systems Technology: Development and Application, Englewood Cliffs, New Jersey: Yourdon Press, Prentice - Hall Company.

[19] Lee, D.M. (1983), "Time Impact Analysis- Forensic Scheduling Liability in Construction Management, Proceedings of Symposium of the Construction Division, ASCE, in conjunction with ASCE Convention, Houston, Texas.

[20] Nash, A. and Ball, D. (1982), An Introduction to Microcomputing in Teaching, Hutchinson \& CO. Ltd.

[21] Odeyinka, H.A. (2003), The Development and Variation of Models for Assessing Risk Impacts on Construction Cash Flow Forecast, PhD Thesis, Glasgow Caledonian University, Glasgow.

[22] Paek, J.H.; Lee, Y.W.; and Ock, J.H. (1993), "Pricing Construction Risk: Fuzzy Set Application", Journal of Construction Engineering and Management, ASCE 119 (4), pp: 743 - 755.

[23] Polya, G. (1969), Mathematics and Plausible Reasoning, Vol. 2 Patterns of Plausible Inference Pricetown University Press.

[24] Project Management Institute (2008), A Guide to the Project Management Body of Knowledge, 4th Edition, Project Management Institute, Pennysylvania.

[25] Reason, J.T. (1995), “Understanding Adverse Events: Human Factors”, In Vincent, C.A., Ed.,Clinical Risk Management, London: BMJ Publications.

[26] Royal Institute for Chartered Surveyors (2012), "Modelling Risk Impacts on the Variability between Contract Sum and Final Account”, Research report, September, 2012.

[27] Schuttle, D; Stephen, W. and Liska, W.R. (1994), Building Connstruction Estimating, Singapore: McGraw Hill Book Company. 
[28] Siler, W. (2000), Building Expert Systems, from http://members.aol.com/wsiler.

[29] Slatter, P.E. (1987), Building Expert Systems: Cognitive Emulation, England: Ellis Horwood Limited.

[30] Smith, N.J.; Merna, T.; and Jobling, P. (1999), Managing Risk for Construction Projects, London, U.K.: Blackwell Science Ltd.

[31] Worthington, J. (1994)," Design in Practice - Planning and Managing Space”, In : Spedding, A. (Ed.) (1994), CIOB Handbook of Facilities Management, Harlow: Longman Group.

[32] Zadeh, L.A. (1965), ” Fuzzy Logic and Approximate Reasoning”, Synthese, 30, pp. 407-428.

\section{Authors}

Ibrahim Yakubu was born in Bauchi, Bauchi State, Nigeria. He attended Ahmadu Bello University, Zaria, Nigeria; University of Jos, Nigeria and Abubakar Tafawa Balewa University, Nigeria. He is a Registered Quantity Surveyor and a Professor of Construction Management at Abubakar Tafawa Balewa University, Bauchi, Nigeria. His research specialization is in Application of Information Technology to Construction Management. His hobbies include reading, writing and travelling. He is married with children. 